Growing Old in the future 
Translation from Dutch by: C.N. ter Heide-Lopey 
C.F. Hollander

H.A. Becker (Eds.)

\section{Growing Old in the Future}

Scenarios

on health and ageing

1984-2000

Scenario-report, commissioned by the Steering Committee on Future Health Scenarios

1987

Martinus Nijhoff Publishers

A member of the Kluwer Academic Publishers Group

Dordrecht - Boston - Lancaster 
for the United States and Canada: Kluwer Academic Publishers, P.O. Box 358, Accord Station, Hingham, MA 02018-0358, USA

for the UK and Ireland: Kluwer Academic Publishers, MTP Press Limited, Falcon House, Queen Square, Lancaster LA1 1RN, UK

for all other countries: Kluwer Academic Publishers Group, Distribution

Center, P.O. Box 322, 3300 AH Dordrecht, The Netherlands

Library of Congress Catalog Card Number 87-11047

ISBN-13: 978-0-89838-869-5

e-ISBN-13: 978-94-009-3309-5

DOI: $10.1007 / 978-94-009-3309-5$

(C) 1987 Bohn, Scheltema \& Holkema bv, Utrecht

All rights reserved. No part of this publication may be reproduced, stored in a retrieval system, or transmitted in any form or by any means, mechanical, photocopying, recording, or otherwise, without the prior written permission of the publishers.

Martinus Nijhoff Publishers, P.O. Box 163, 3300 AD Dordrecht, The

Netherlands. 


\section{Preface}

This publication represents the report of the Scenario Committee on Ageing. The draft report was discussed with a wide range of experts, inter alia during the symposium 'Growing old in the Future' held on October $27 \mathrm{th}, 1984$. In addition to the scenario report, a background report containing the basic analysis employed in the scenarios on ageing has been prepared. The scenario report has been written in such a way that it can be read independently of the background study.

Scenarios are a relatively new phenomenon in health care and related policy. For this reason it might be useful to furnish the reader with a few suggestions.

As a first step, perusing the summary will provide the reader with an overall picture of this application of the scenario method in policy preparation and policy implementation in the sector health of the elderly.

As a second step, we would recommend that the scenario report be read in its totality. It might be useful to note down points on which the reader would like to make additions or variations.

Subsequently, it might prove beneficial to study both the scenario report and the background report in order to consolidate one's own ideas with respect to additions and variations, and to set down on paper in greater detail what might be the possible influences of contexts on patterns of care in order to be able to weigh the various effects. In this third stage, the as yet unpublished Policy Memorandum on Health in 2000 will no doubt also play a role. The reader will probably desire to study the policy memorandum in the light of the scenarios. In this stage, many readers will also want to take account of the reports of the other scenario committees. One thing that will be realized is that the four scenario reports only deal with a limited number of the aspects dealt with in the Policy Memorandum on Health in 2000. It is consequently the intention of the Steering Committee on Future Health scenarios also to devote scenarios studies to various other subjects. 
During the implementation of the scenario project on ageing, information and co-operation was obtained from many sources. We would like to thank all concerned for their support and valuable contributions.

Scenario Commission on Ageing

Research Team

Leidschendam/Utrecht, January 1985 


\section{Table of contents}

Page

Summary

$1-34$

1 Introduction

1.1 Background

1.2 Design and course of the scenario project on ageing

1.3 Taking a further look at scenarios 41

1.4 Design of the report

\section{Scenario A: The reference scenario}

2.1 Introduction

2.2 Demographic developments 52

2.2.1 Population size $\quad 52$

2.2.2 Composition of the category of elder1y 54

2.3 The state of health of the elderly 55

2.4 Social developments $\quad 64$

2.4 .1 Introduction $\quad 64$

2.4.2 Educational level of the elderly 65

$\begin{array}{ll}2.4 .3 & \text { Emancipation of the elderly }\end{array}$

2.4 .4 Reduced number of children 68

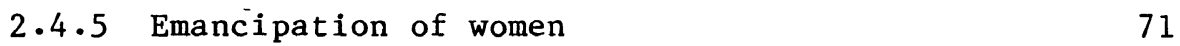

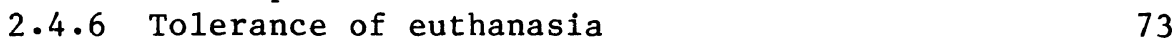

2.4.7 Improvement of pensions 75

2.4.8 The position of the elderly in society 78

2.5 The demand for (health) care facilities 78

2.5 .1 Introduction $\quad 78$

2.5.2 The development of facilities 81

2.5 .3 GP care $\quad 82$

2.5.4 Ambulatory mental health care 88

2.5 .5 Homes for the elderly 91

2.5 .6 Nursing homes 96

2.5.7 Day treatment in nursing homes 98

2.5 .8 Hospitals 100

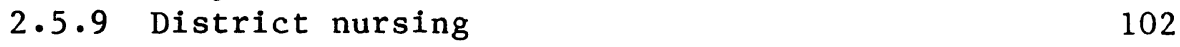

2.5 .10 Home help 105

2.5.11 Dwellings for the elderly 107

2.5.12 Co-ordinated work for the elderly 111

2.6 The economic context 112 
3 Medical and medical-technological developments

3.1 Introduction

3.2 Expectations with respect to medicine and pharmacology

3.3 Expectations with respect to technology 133

3.3.1 The costs aspect

3.3.2 Medical-technical apparatus 134

3.3.3 Technical aids 134

3.3.4 Nursing 136

3.3.5 Information technology and epidemiology 136

3.4 Towards a second medical revolution? 136

3.5 Expectations with respect to cell biology 138

3.5 .1 What is ageing? 138

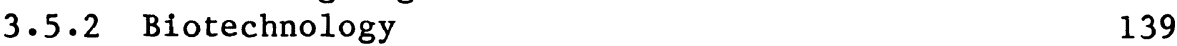

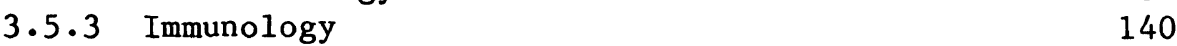

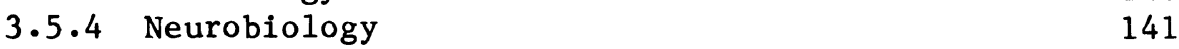

3.5 .5 Conclusion 141

3.6 Concluding remarks 142

4 Scenario B: Increasing growth in demand for facilities

4.1 Introduction

4.2 Social developments as they affect the health situation

4.2.1 The elderly of the future

4.2.2 Values and norms as applying to the elderly

4.2.3 Volunteer work

4.2.4 Decreasing solidarity

4.2.5 Attitudes to sickness and health 152

4.2.6 Increasing professionalization 153

4.3 Consequences for facilities 155

4.4 The economic context 157

5 Scenario C: Decreasing growth in demand for facilities

5.1 Introduction

5.2 Social developments as they affect the health situation

5.2.1 Altered attitudes with respect to sickness and health 
$\begin{array}{lll}5.2 .3 & \text { Pensioning } & 169\end{array}$

5.2.4 Long-term consequences for health 173

5.3 Developments relating to facilities for the 174

$\begin{array}{ll}5.3 .1 & 174 \\ 5.3 .2 & 174\end{array}$

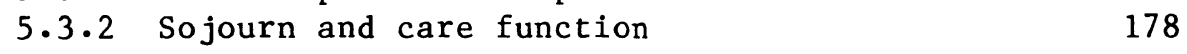

$\begin{array}{ll}\text { 5.3.3 Nursing and medical treatment } & 182 \\ \text { (diagnosis and therapy) } & 184\end{array}$

5.3.4 Conclusions with respect to facilities 184

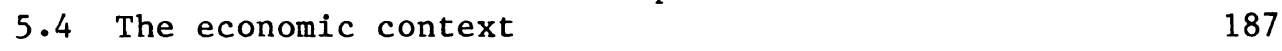

\section{Disturbing developments}

$\begin{array}{lll}6.1 & \text { Introduction } & 191\end{array}$

$\begin{array}{ll}6.2 \text { Postponement of dementia } & 191\end{array}$

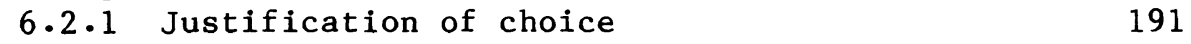

6.2.2 Some epidemiological aspects of dementia 192

$\begin{array}{ll}6.2 .3 & \text { Medical-technological developments } \\ \text { relating to dementia } & 196\end{array}$

6.2.4 Towards a calculation model 198

6.3 Extreme decrease in intergenerational solidarity 201

6.3 .1 Justification of choice 201

6.3.2 Some basic data on the aid relationship
children-parents

6.3.3 Towards a calculation mode1 205

6.4 Intersecting developments in relation to the
scenarios

7 Application possibilities for scenarios

7.1 Introduction 212

7.2 Scenarios as 'learning environments' 213

7.3. Scenarios and health care facilities 214

7.4 A closer look at putting the scenario report 218

$\begin{array}{ll}7.5 \text { Concluding remarks } & 219\end{array}$

$\begin{array}{ll}\text { Appendices } & 253\end{array}$

$\begin{array}{lr}\text { Glossary } & 289\end{array}$

$\begin{array}{ll}\text { Bibliography } & 294\end{array}$ 